\title{
CAPITAL KNOWLEDGE OF THE INDIGENOUS: AN APPRAISAL OF ZA'BA'S THOUGHTS ON LANGUAGE AND LINGUISTICS
}

\author{
Asmah Haji Omar \\ University of Malaya
}

\begin{abstract}
Za'ba, Malay linguist of the 20th century, had already begun analysing the Malay language using empirical data since the 1920s. His approach is manifold: reflective, discursive, context-based, inductive and prescriptive. Many of his ideas seem to be precursors to certain theories in grammar, phonology and graphology, semantics and discourse, which linguists of today are familiar with through books written by Western scholars with data from other languages. However, Za'ba was not familiar with those theories when he wrote his books on Malay and used them in teacher-training at the Sultan Idris Training College, Tanjong Malim, and those theories were not yet well-published at the time. This paper is an appraisal of his thoughts on language, its primary role in thinking, and the teaching of language where all systems should be treated in a holistic manner.
\end{abstract}

KEYWORDS: CAPITAL KNOWLEDGE, ZA’BA, THOUGHTS, LANGUAGE TEACHING

\section{Introduction}

The main thrust of my paper is that there is a great deal of information out there, or rather within the Malay world, which points to the existence of indigenous Malay scholarship. People are aware that the Malays in pre-modern times, let's say before the Second World War, produced a lot of writings. Apart from works that are categorised as creative literature, they also wrote on a number of things, such as language, literary treatises, socio-cultural issues, economics, religion, ethics and legal digests. While these writings are phenomena-based, they are also reflective in character given that the authors do only describe and narrate but also offer their own thoughts on the subjects before them. While writings of this category are valued as Malaysia's heritage, their status as academic or scientific texts is not easily forthcoming. There may be several reasons for this, and one needs to look at the texts to identify these reasons.

It is not within my academic capacity to examine texts in the various branches of the social sciences and the humanities. Hence I have chosen the study of the Malay language which has received much attention from scholars, Malays and Westerners, specifically the British and the Dutch. However, due to time constraints, I have decided to focus on one particular scholar, Zainal Abidin bin Ahmad, better known as Za'ba, for the fact that his thoughts on language, and in particular the Malay language, are unknown to or almost forgotten by present-day scholars of the Malay language, whereas before the 1970s his works, especially Pelita Bahasa Melayu, and Ilmu Mengarang Melayu were about the only reference books of a comprehensive nature on the Malay language. By "comprehensive", I mean that these books deal with all aspects of language, not just spelling and grammar. Even his Rahsia Ejaan Jawi is not just about writing and spelling Jawi but also about grammar 


\section{CAPITAL KNOWLEDGE OF THE INDIGENOUS: AN APPRAISAL OF ZA'BA'S THOUGHTS ON LANGUAGE AND LINGUISTICS}

\section{Za'ba and his works}

Zainal Abidin Ahmad (1895 - 1973) was born in Negeri Sembilan and received formal education in Malay and English. His schooling in Malay was only at the primary level as there were no secondary schools in the Malay language medium during his time. So he continued his education in the English school at the end of which he obtained the Senior Cambridge Certificate. As a young boy he learned Arabic as part of the religious tuition given to him by a family member in his kampong. He later went on to receive a diploma in Arabic at the School of Oriental and African Studies, University of London, when he was sent there to teach Malay.

Za'ba started his career as a teacher in the English school in Johor Baharu and later on at the Malay College Kuala Kangsar. His interest in the workings of the Malay language began when he tried to compile a dictionary of the Malay language while he was still a teacher in Johor Baharu, but abandoned this project halfway because the writing and spelling of Malay in Jawi (the main script used for Malay at that time) got in the way due to its "haphazardness", and he felt that he should put the Jawi spelling in order first before working on the dictionary. His subsequent appointment as head of the Translation Bureau of the Pejabat Karang Mengarang Melayu, primarily an office of the Education Department of the colonial government with the specific duty of publishing books for the Malay schools and translating works from English to Malay also for use in the schools, gave him more space, as it were, to ponder on the Malay language. As the Pejabat Karang Mengarang was housed in the same premises as the Sultan Idris Training College (SITC) in Tanjong Malim, a teachers' college training teachers for the Malay schools, Za'ba's expertise was also made use of as a lecturer in this college, teaching Malay to the teacher trainees. In today's lingo we can say that these appointments gave him the language data and the hands-on experience which enabled him to write about the language.

The first book that launched him as a linguist of the Malay language was Kitab Ilmu Bahasa Melayu I and IT, which was published in 1927, followed later by Rahsia Ejaan Jawi (1929), Ilmu Mengarang Melayu (1934), and Pelita Bahasa Melayu Penggal I (1940), Penggal II (1946) and Penggal III (1949). All these were published by the Malaya Publishing House Ltd. Singapore for the Education Department under the Malay Home Study Series. During this time Za'ba also wrote on many other subjects - Islam, ethics and the socio-economic situation of the Malays - in both Malay and English, most of which were published in journals, such as Majalah Guru, Al-Ikhwan and the Journal of the Malayan Branch of the Royal Asiatic Society (JMBRAS).

Before becoming a linguist Za'ba was a social critic, giving views which were against the interest of the British colonial government. This he continued even after he had become a linguist. According to economist Royal Professor Ungku Abdul Aziz, Za'ba was the first man ever to talk about the poverty of the Malays as early as the 1920's, and to suggest remedies to overcome the situation the Malays were in specifically in a competition with the new settlers, namely the Chinese and the Indians. Ungku A. Aziz (1976). His main ideas on the economic situation of the Malays can be found in two articles, "The Poverty of the Malays", and "The Salvation of the Malays", which appeared in the Malay Mail, published in five parts in December 1923. His ideas were a threat to British rule at the time. As a result he was transferred from place to place at short notices, until his Tanjong Malim appointment which lasted for 15 years. His alignment with the Islamic Reform Movement, the Kaum $M u d a$, was also viewed in a negative light as he was considered to be too progressive for his time. Hence Tanjong Malim appeared to be the solution for the British masters to deal with Za'ba.

Tucked away in this small village was college, built in 1922, for Malay boys who had passed their six years of primary education in the Malay schools in the kampongs. This was the only institution then 


\section{CAPITAL KNOWLEDGE OF THE INDIGENOUS: AN APPRAISAL OF ZA'BA'S THOUGHTS ON LANGUAGE AND LINGUISTICS}

which offered a post-primary education to the Malays, in the Malay language. The brightest of these boys were brought here from the Malay states, including Singapore and Brunei, to undergo a threeyear training as teachers of the Malay school. They were still young teenagers when they came to this college, known as the Sultan ldris Training College (or the SITC for short). The physical surroundings and the population of the college were thought to be a safe place for such an intellectual renegade as Za'ba who was transferred there in 1924 . He was given the task of teaching the Malay language to these teacher trainees, but his main responsibility was as head of the Translation Bureau of the Pejabat Karang Mengarang Melayu, which produced textbooks for the Education Department of Malaya. (For Za'ba's many sojourns in his career, refer to Abdullah Hussain and Khalid Hussain (1974), and Adnan Nawang (1998).

The Tanjong Malim appointment which lasted for 15 years (1924 - 1939) proved to be a watershed in Za'ba's career as a linguist. His language courses and his translation, mainly of English literary works to Malay gave him an insight into the workings of language, not just in terms of the rules of grammar and phonology but also in terms of the functions of the language systems in the mind and in the cultural life of the speakers. Editing and writing the texts which were meant for the schools as well as for popular reading had definitely sharpened his conception of what a good discourse should be, and he has recorded his line of thinking in the guidelines (petua-petua) for good writing.

One thing the British rulers did not contend with when they instructed Za'ba to move to Tanjong Malim was that he was in a better position in this small village than anywhere else to sow the seeds of nationalism among the younger generation. The extra-curricular activities that he organised within the ambit of the students' associations gave him every opportunity to impart to them his ideas on the importance of defending the dignity of the Malays as a race. In the Malay language classroom, the examples that he gave for language exercises and for essay writing to the teacher trainees were those that evoked the feelings of nationalism. His books especially Pelita Bahasa Melayu (PBM) and Ilmu Mengarang Melayu (IMM) are attestations to this. Za'ba and his students some of whom later became lecturers at the college can be given the credit for making the SITC the earliest nursery for Malay nationalism.

Za'ba's writings on language, and particularly the Malay language, can be divided into two main categories: one which looks at language as a socio-political institution which reflect the ethos of Malay nationalism of the time, and the other which deals with language as a verbal system which the human being makes use of as a tool for thinking - this category may be placed under linguistics proper.

His works in the first category are in the form of an assortment of essays published in local journals, especially the Majalah Guru, in which he discusses the role of Mal ay as an identity of the Malays, inclusive of the ethnic groups of Indonesia who call themselves Malays. It is in these articles that he plants the idea of making Malay the national and official language of Malaya. According to him language has a soul (jiwa) and it reflects the culture of the people. And the soul of the Melayu jati (the genuine Malay) is in the bahasa Melayu jati (the genuine Malay language). One can say that these articles were politically motivated, in tune with the nationalist movement that was fermenting in the 1930 's.

The more significant of these two categories of writing is the second one, the linguistics works which have been published under four titles: Kitab Ilmu Bahasa Melayu Penggal I \& II, Rahsia Ejaan Jawi, 


\section{CAPITAL KNOWLEDGE OF THE INDIGENOUS: AN APPRAISAL OF ZA'BA'S THOUGHTS ON LANGUAGE AND LINGUISTICS}

Ilmu Mengarang Melayu, and Pelita Bahasa Melayu Penggal I, II \& Ill. The Pelita Bahasa Melayu $(P B M)$ is an enlarged and improved version of Kitab Ilmu Bahasa Melayu (KIBM). These works contain not only rules in language usage but also Za'ba's philosophy of language. As such the discussion in this paper will be confined to the philosophy of language as found between the covers of these books.

\section{Za'ba's approach to language}

Za'ba's approach to language is manifold. He is both reflective and discursive. Moreover, he does not only describe linguistic phenomena but he also interprets these phenomena according to what he believes language should be. Below is an attempt to summarise the various approaches utilised by Za'ba in his works.

\section{Empirical}

In his time there was no tape recorder for Za'ba to record his data in the way modern field linguists do. Nevertheless, he had empirical data, i.e. the everyday language as used by Malay native speakers. In positing the rules of grammar and pronunciation, he keeps referring to the native speaker. He recognises native variations as defined by the geographical distribution of the language, but the differences according to him are minor and each regional variety has its own place within its own context. As his writings are also for a prescriptive purpose, and in line with the target group for which his books were written i.e. teacher trainees, he recommends the Johor-Riau Malay as the norm. The other dialects such as those from Kedah, Kelantan, Perak, Terengganu etc. are considered only as oral languages (gaya bahasa mulut or gaya cakap mulut), and hence are not taken as the norm in language teaching. He notes that in these geographical regions, there is one general written form (bahasa surat), and that is the one based on Johor-Riau Malay. His choice of the Johor-Riau variety as the standard language lies in the language of Sejarah Melayu which is that of the Johor-Riau, and to him it is the epitome of good Malay usage. He recommends that one reads the Sejarah Melayu and the hikayat if one wishes to master the Malay language.

When Za'ba wrote his books, bahasa Indonesia was still in its infancy as the unifying language of the Indonesians, then known bahasa persatuan. As we know from history, the variety of Malay from which bahasa Indonesia evolved was the lingua franca variety spoken by people in various parts of the archipelago. In his book Ilmu Mengarang Melayu, Za'ba states that bahasa Indonesia at that time was bahasa kacukan ( a Creole), but concedes that it would develop into a better form with time. This is a very interesting point because in the 1920's and 1930's there was this debate among the Bible translators of the British Foreign Bible Society (BFBS) and the Netherlands Bible Society (NBS) on the variety of Malay to be used in the translation of the Bible into Malay, the Peninsula variety (which was considered high Malay and used by William Shellabear in his translation of the Bible) or the Java-based variety (which was used by C. Klinkert and considered a pidginised variety by the British side). There was an effort between the two to produce a union of the two translations, perhaps with each side coming half way not only in compromising the styles, but also in the resources expended. As the story goes, the British side paid their half of the financial support but stuck to the variety they had chosen from the beginning Robert Hunt (1996). I do not think that Za'ba was in any way influenced by the polemics of the Bible translators. His conviction that the Johor- Riau Malay was the best variety of Malay arose from his broad knowledge of Malay c1assical literature and the Malay world. 


\section{CAPITAL KNOWLEDGE OF THE INDIGENOUS: AN APPRAISAL OF ZA'BA'S THOUGHTS \\ ON LANGUAGE AND LINGUISTICS}

Za'ba's attitude towards bahasa Indonesia changed over the years. He was a leading figure in the effort to unify the spelling system of Malaya and Indonesia which germinated in the 1950's in the First Congress of Bahasa Melayu (1952), followed by the Second Congress (1956) which offered the earliest formulation of a common spelling system for Malaysia and Indonesia. (Asmah Haji Omar 1992: Chapter 10). It was this 1956 formula that became the basis of the Melindo Spelling System of 1959 agreed upon by Malaya and Indonesia but which was never implemented. Za'ba acted as advisor to the Malayan spelling team in this negotiation (Asmah Haji Omar 2004: Chapter 5).

\section{Inductive}

Za'ba's approach was also inductive, specifically in the formulation of rules. His grammatical rules are based on the language that was spoken around him. To him it is data that supplies the rules, not the other way round. Because of this, his formulation of grammar is very much in contradistinction to the minimalist stance in the generative grammar that many present-day Malaysian linguists subscribe to. Another very good example of his inductive approach is his spelling system, Ejaan Zap 'be, which came to be known as Ejaan Secular for its use in schools from 1933 to 1972. This spelling was a revision of the spelling system formulated in 1904 by a committee chaired by R.J. Wilkinson, known as Ejaan Wilkinson. Za'ba revised the Wilkinsan System because he found this system did not reflect the sounds of Malay, i.e. the way the Malays pronounce the language. A clear sign of the disparity between the spelling according to the Wilkinsan System and the pronunciation of the language is in the writing of vowels in final closed syllables. For example, the high vowels $u$ and $\mathbf{i}$ in telur and itik do not exist in any native speaker variety of Malay. So Za'ba changed the vowels in such contexts to $\mathbf{O}$ and $\mathbf{e}$. In his own words, his re- formulation of the spelling system arose out of his concern for the preservation of bahasa Melayu sejati or the genuine Malay language.

\section{Holistic}

Za'ba's treatment of language systems is holistic. That is to say, any single system, for example phonology, morphology or syntax, is not treated monolithically as though it is an independent entity, meaning that the existence of one system depends entirely on the other or others. Hence, his treatment of the phonology of Malay is done together with his treatment of morphology and vice versa. This approach came about due to his clear conviction that language functions as a vehicle of thought, and in order to convey a complete thought all the systems have to function in unison.

An obvious illustration to any researcher who seeks to understand this particular approach of Za'ba's lies in the Jawi script which was the script for writing Malay during his time. The script, being syllabic, shows that a single character can represent a syllable (in which case it belongs to the level of phonology) or an affix (in which case it belongs to the level of morphology or grammar). That is why when Za'ba uses the term hurufin, he does not intend it to mean the graphic character as we understand it to be, but a grammatical unit which is dependent on another unit, usually a word, which in modern linguistics is known as a bound morpheme. The writing or spelling in Jawi also reflects immediate constituents in sentences. In Jawi the directional preposition $k e$ as represented by the character kaf is written by connecting it to the word that follows it. The reason for this may be due to the writing style or to the fact that kaf cannot stand in its full form separated from other characters. 


\title{
CAPITAL KNOWLEDGE OF THE INDIGENOUS: AN APPRAISAL OF ZA'BA'S THOUGHTS ON LANGUAGE AND LINGUISTICS
}

Added to these reasons is one which is most cogent in terms of the grammar of Malay, and that is ke as a particle can only exist as a grammatical element when it is linked to the word that follows it. So the link in grammar has to be shown in writing, and the graphic property of kaf makes this possible. This holistic stance was transferred to Rumi, but the representation in Rumi of the grammatical link is reflected in the use of the hyphen. This reflects Za'ba's awareness that while the systems are interlinked, care must be taken so as not to confuse the systems to which the various grammatical elements belong, especially those which are homophonous. As the directional preposition under consideration is homophonous with the prefix ke-in ketua and kehendak, the use of the hyphen serves to differentiate the particle from the prefix. The same treatment is given to the preposition $d i$ and the prefix $d i$.

\section{Context-Based}

Za'ba's explanations of the rules of grammar are context based. The context is given not within the confines of single grammatical elements or systems, but in terms of the totality of the discourse. Modem linguistics and more so generative grammar has never looked at discourse as the context or rather the matrix wherein lie the bases and the explanations to language rules. The importance of discourse in linguistics only came into the fore for modem linguists in the second half of the twentieth century with the publication of Grice's maxims (1957) and Austin speech act theory (1960). Grice summarises his four principles in discourse as quantity, quality, relevance and manner. Za'ba however had already formulated these principles (although he never uses those terms) most clearly in Chapter 1 of his Ilmu Mengarang Melayu which was first published in 1934. His principles of quality and relevance are given in paragraph 17 of the chapter:-

\section{Isi yang hendak diperoleh itu pula endaklah yang layak dibawa masuke medan, jangan perkara yang kecil-kecil yang semata-mata kelak menunjukkankebodohan dan cetek fikiran pengarang itu sahaja.}

He speaks of quantity in terms of menyukat sebanyak mana hendak disebut, and manner in terms of bagaimana menyusun cakap.

\begin{abstract}
Susunan (ikatan) ayat jangan berbolot-bolot, dan perkataan hendaklah jangan pada yang bukan-bukan tempatnya. Karangan hendaklah kemas, serta ikhlas bunyinya hendak memberi orang faham.fangan seperti hendak menunjuk-nunjuk pandai atau mengada-ngada. (paragraph 22).
\end{abstract}

all this means is that teaching of grammar has to be done together with the teaching of the skills such as speaking and especially writing. Grammatical rules are the infrastructure of the language, and knowing the language in its use in context gives the learner a ready understanding of the workings of language.

Another example of his context-based teaching is the teaching of the meaning of words. To Za'ba, the word is the primary element in language, because it is in the words lie the meaning of what we say. So teaching the meaning of words cannot be done in any other way but within the context in which the word is used. A favourite exercise in the Malay language classroom in Malaysia is matching words in synonymy, i.e. words are given in a jumble in two different columns and learners are required to use the arrow symbol to pair them off, and the result are pairs of synonyms. Za'ba says there no real synonyms (perkataan setara atau seerti), because there do exist what he calls pecahan- 


\title{
CAPITAL KNOWLEDGE OF THE INDIGENOUS: AN APPRAISAL OF ZA'BA'S THOUGHTS ON LANGUAGE AND LINGUISTICS
}

pecahan maksud or distinguishers. As such, gemar, suka, ingin are not synonyms in the real sense of the word, because in context they show difference in meaning. He further states,

\begin{abstract}
Hendak mengenal perbezaan-perbezaan yang halus ini wajiblah banyak membaca karangan pengarang yang pandai-pandai dan endengar percakapan orang Melayu jati di kampung-kampung. (MM: 146; the whole of Bab(Chapter) VIII)
\end{abstract}

What he prescribes is that the teaching of so-called synonyms has to be done in context. Otherwise, learners will be led into the belief that there are words which are $100 \%$ identical in meaning whereas in reality this is not the case. And his treatment of such words which he prefers to call perkataan setara is very much in line with what is known as the semantic field theory where words that overlap in meaning are known as belonging to the same semantic field, and the non-overlapping part in their meaning are known as distinguishers (which Za'ba calls pecahan-pecahan maksud). And this theory only came into being in the second half of the $20^{\text {th }}$ century.

\section{Describe and prescribe}

All of Za'ba's writings on the Malay language combine the descriptive and the prescriptive. He describes every single aspect that he sees in a single system, and immediately he prescribes what he deems as good usage. Not for him the demarcation of what exists and what should be. This combinatory approach could have arisen due to two factors. Firstly, to Za'ba, what exists and what is preferred should be shown together to provide an understanding among language users of the language they should acquire as correct Ma1ay (Melayu betuli). Secondly, and this follows the first reason, his books were primarily written for teacher trainees, and this group of people should know both sides of the coin for them to be able to be better teachers of the language.

\section{Za'ba's views of language}

Za'ba has a set of views or beliefs on language in general, not just on the Malay language. First and foremost he never defines language as a tool for communication. To him language is a tool for thinking. As such, there should not be any separation between language and thought. Good thinking is reflected in correct language. And tied to thinking is behaviour, as behaviour is an outward reflection of thought. The link between language, thought and behaviour is crystallised in the maxim Bahasa Jiwa Bangsa which has become Dewan Bahasa dan Pustaka's motto. This expression arises from the belief that language has a soul, as do the people who speak it. If this is the epistemology that is reflected in this motto then language should not be taken to mean a tool of communication which is translated into an act of behaviour. Rather it is the product of the processes that goes on within one's mind. This epistemology has a bearing on the method of teaching the language that he recommends.

Za'ba recognises that language is characterised by various levels of speech. As it pertains to Ma1ay, he lists out these levels as bahasa Melayu tinggi, bahasa pasar, bahasa kacukan, gaya cakap mulut, dan gaya bahasa tu lis.

In sociolinguistics there is the term high language which can be translated as bahasa tinggi in a diglossic situation where the opposite is low language or bahasa rendah. Although this schema is universally agreed upon by sociolinguists, the interpretation of what represents each level varies 


\section{CAPITAL KNOWLEDGE OF THE INDIGENOUS: AN APPRAISAL OF ZA'BA'S THOUGHTS ON LANGUAGE AND LINGUISTICS}

according to the community's value system. In Za'ba's time, the value system of the Ma1ays gave great weight to upbringing where high social, moral and religious standards were upheld. Hence, to him bahasa Melayu tinggi is a variety that reflects these standards, besides the fact that it has to be intellectualised. In sum bahasa Melayu tinggi has two properties: finesse and intellectualization. In fact to attain and speak Za'ba's bahasa tinggi, specifically its fmesse component, one does not have to be school-educated or to stay among the urbanites.

The interpretation of bahasa tinggi among modem-day Malaysian sociolinguists seems to only focus on the intellectualisation property, specifically that the language can be used in the teaching of academic subjects. For as long as the language has a sufficient corpus of technical terms in the various branches of the academia it becomes bahasa tinggi. Finesse which takes the speaker to the highest level of social decorum in his/her use of language appropriate with the situational frame of the language in use, seems to be sidelined. To Za'ba, while the Malay language has to be the conveyor of high-level thinking, as embodied in what he terms karangan tinggi, the language has to be halus or have finesse. When Za'ba speaks of finesse he does not stop at producing grammatical sentences as the rule is in modern structural and generative linguistics, he also points to the importance of what he calls bunga-bunga bahasa, referring to the use of idioms, proverbs, metaphors, various figures of speech, different styles (ragam bahasa), etc., each having its purpose in usage. He emphasises these elements as belonging to cabang-ea bang tinggi which can be translated as higher levels of language usage.

\section{The Malay sounds and their visual representation}

Za'ba recognises the primacy of the spoken sound (which is internal to language) over the written symbol (which is external to language). This explains his formulation of the Rurni spelling system. To him spelling rules should be formulated to reflect the pronunciation of words according to what is normal for native speakers, and for the schools he advocated the Johor-Riau as the standard pronunciation. He had misgivings over the Wilkinson system of spelling as it had produced a pronunciation that was not Malay, especially among the English learners of Malay.

As Jawi and Rumi belong to two different writing systems, Za'ba cautions that the two systems should be kept apart (one should not be used as the basis for the other). He sees the Jawi writing as rooted in the Malay culture, and that being the case he objects to the system being called huruf Melayu or tulisan Melayu. According to him, the term Jawi is more appropriate because it is a system which has been taken over from Arabic and given modifications to suit the Malay language, and at the same time it is also used to write Arabic words. If it is huruf Melayu or tulisan Melayu it is just for the writing of the Malay language.

Za'ba's re-formulation of the Jawi spelling as given in his Rahsia Ejaan Jawi (first published in 1929) was to strengthen this item of the Malay culture. In the 1920's he had witnessed the threat faced by tulisan Jawi with the fast advancing tulisan Rumi, and in Indonesia Jawi was relegated into the background even in the teaching of the Quran. His despair at seeing the diminishing role of Jawi is given in the following quote:-

Bahawa dengan hati yang tawar dan sebal sedikit rasanya dikernukakan kitab Rahsia Ejaan Jawi in ke hadapan pernbaca- pernbacanya. Tawar dan sebal oleh melihatkan kecenderungan tulisan Rurni bahasa Melayu makin bertambah-tambah maju dan kern bang narnpaknya di antara anak-anak Melayu.(REJ: Pendahuluan) 


\section{CAPITAL KNOWLEDGE OF THE INDIGENOUS: AN APPRAISAL OF ZA'BA'S THOUGHTS \\ ON LANGUAGE AND LINGUISTICS}

Za'ba blames the Dutch for the demise of Jawi in Indonesia, and at the same time he commends the British for keeping the system alive. At this juncture, it is pertinent for me to cite once again the activities in Bible translation by both the British and the Dutch. While the Dutch had from the beginning used Rumi with the Dutch-based spelling, the British first produced their Bible translation in Malay, in Jawi. It was only much later that the Malay translation of the Bible was transliterated into Rumi, using the English-based spelling. Jawi preservation which was upheld in the British era continued until after independence, in its teaching in the school. During the colonial period government officers, both local and expatriate, had to pass the Jawi examination in order to be able to get promoted in their jobs. However, if Za'ba were to live to this day he would certainly blame the Malaysian government for the almost complete disappearance of Jawi as an important element in the Malay cultural life.

In his Rahsia Ejaan Jawi, Za'ba combines orthography with graphology. These two features have to be taken together as the Jawi system is syllabic, and he also sees the Jawi writing as an art form. The characters in the system are discussed in terms of their historical evolution, phonetic value, morphological potential, and calligraphic possibilities. He emphasises the nature of Jawi as syllabic, and he decries the practice of turning the system into one which uses the vowel signs when these vowels are not needed. According to him such a practice shows ignorance of the writing system itself on the part of the formulators of the spelling system.

\section{Za'ba's views of language learning and teaching}

In his works Za'ba repeatedly points out that the Malays of his time do not know how to speak and write well. Because of this, they produced very little literature, unlike the English. He attributes this to two factors: the first being their lack of reading, and the second, and this is relevant to the subject of discussion here, is their inability to organise their thoughts in good language. What Za'ba means here is, thought and the organisation of thought are one. This goes back to his definition of language as a tool for thinking. Arising from this, language proficiency to him means the ability to use language most efficiently in expressing one's thought. Hence, language teaching should consist of activities which train the student to organise and express his/her thought in good language. This is a philosophy of language which makes his method of language teaching more difficult for the language teacher compared to the present method of teaching language for communication.

In Za'ba's epistemology, grammar should not be taught in terms of rules. There is no need to dissect the human speech into parts to teach the language to the learner. The rules are explicit in the language in use. A good example is the baby who does not know any grammatical rules when he learns to speak. Za'ba goes on to liken language learning to many human activities. An example is riding the bicycle. One does not need to dismantle the bicycle into parts in order to ride it. All that one needs to do is to ensure that the parts are working in unison with one another. So what the teacher is required to do is to go straight into teaching the student to speak and write well.

Nevertheless, Za'ba places two caveats in this stance. One is that the language teacher must know the rules of language; this is necessary to enable him to explain to his pupils the correctness and incorrectness of forms. This means that teaching of rules is necessary at the teacher training level. The second caveat is in the teaching of a language which is not the student's language. Za'ba uses the term bahasa asing, but this term currently has a fixed reference which takes into account the role of language in the student's speech community. So Za'ba's bahasa asing not only means foreign 


\section{CAPITAL KNOWLEDGE OF THE INDIGENOUS: AN APPRAISAL OF ZA'BA'S THOUGHTS ON LANGUAGE AND LINGUISTICS}

language but includes second language as well. Za'ba contends that in this type of a situation some exposition to the rules is needed. For example the Malay language learner needs to be told of the nominal phrase pattern as in rumah besar and rumah putih which is the norm, while besar rumah and putih rumah are incorrect.

Again in Za'ba's epistemology, language as a tool for thinking is an abstract entity, and one which has a soul. The best model for this entity is found in the speech of the native speaker (orang Melayu sejati). To produce this entity, a whole gamut of processes is required, not just the physical production of speech sounds, but more importantly the process of forming the thought and organising it according to the rules accepted by the speech community. Za'ba labels the whole process as pembahasaan. This term was first used in Ilmu Mengarang Melayu (1934). There is no definition given to the term but he seems to equate it to the way language is arranged, as given in his explanation of language style (gaya bahasa).

Gaya bahasa ialah rupa susuk bahasa yang dipakai apabila bercakap atau mengarang, iaitu tentang perkataannya, ikatan ayatnya, jalan bahasanya, cara susunan atau bentuk pembahasaannya. (IMM: Bab VI, paragraph 91).

He goes on to explain pembahasaan further in the same paragraph, as follows:-

Gaya bahasa Melayu terbahagi dua --- gaya cakap mulut dan gaya surat. Tiap-tiap satu itu pula boleh jadi gaya Melayu betul atau gaya bukan Melayu. Gaya Melayu betul itu ialah mengikut cara bentuk pembahasaan bahasa Melayu, dan gaya bukan Melayu itu mengikut cara pembahasaan bahasa asing.

Finally comes a definition, in paragraph 92:-

Bentuk bahasa (atau cara pembahasaan) itu ialah kaedah susunan kata yang teradat khas bagi sesuatu bahasa berlainan daripada kaedah lainlain bahasa, baik dalam percakapan atau karangan yang bertulis.

From the extracts above, it can be deduced that pembahasaan refers to both form and the arrangement of forms. However, the following extract shows that pembahasaan means more than that-

\footnotetext{
Bahasa Melayu memang ada bentuk dan susuk bangunnya sendiri dan cara pembahasaannya sendiri. Tidak berkehendak ditirukan bentuk dan susuk bahasa lain. (paragraph 113)
}

If bentuk means form, and susuk bangun structure, pembahasaan has to mean something else, perhaps a superstructure which encompasses both form and structure among other things, and these other things are the mental processes that go with the production of speech and the external contexts which comprise the socio-cultural rules. Following Za'ba, the object which matters in language teaching and language learning is not bahasa or language, the abstract entity, but pembahasaan. The closest English translation to pembahasaan is languaging, Interestingly enough, in the 1980s, applied linguists, specifically those involved in the Teaching of English as a Second or Foreign Language started to focused their attention not on language as such, but on languaging, and their definition of languaging is very similar to pembahasaan. TESL/TEFL students are supposed to acquire a satisfactory attainment level in languaging in English. This means that the focus of TESL/TEFL is not on the product i.e. language as an object, but also on the processes of the production of this 


\section{CAPITAL KNOWLEDGE OF THE INDIGENOUS: AN APPRAISAL OF ZA'BA'S THOUGHTS \\ ON LANGUAGE AND LINGUISTICS}

object.

I don't think any of those TESL/TEFL specialists ever heard of Za'ba, let alone read his works, but the fact that they came up with the concept of languaging indicates a deep reflection and a great deal of research into the process of language learning. Unknown to them this idea had already existed since the early 1930s, half a century before them, in Za'ba's epistemology of language learning and teaching.

\section{Taking stock of Za'ba's epistemology and the developments in linguistic thinking}

Za'ba's linguistics, or ilmu bahasa, as expounded in the four titles under consideration, is in a class of its own. In the linguistic thinking of the twentieth century which extends to this day, a linguistics works or a description of a language is normally framed within the perimeters of one of the main linguistics branches: general linguistics, and discourse analysis (inclusive of both conversational analysis and text linguistics). Even within each of these main frames, one sees the tendency of placing systems within their "walled" compartments, so to speak, without the reference to other systems, because that is the way the thinking goes. So, phonology is discussed without reference to morphology, and morphology can be studied with little use of the sentence which contains the words. And compounded to this, the social and psychological properties of language are considered as separate issues which should not be mentioned in the descriptions of their forms and structures. Za'ba's linguistics, with its holistic nature, does not recognise any barrier between form and structure on one hand, and the social and psychological properties on the other, without which language would not have a soul and a life. In addition, Za'ba's linguistics recognises that any utterance which we call language always exists in the form of a text, not as a de-contextualised sentence.

A shift in orientation in linguistic thinking, alias Western linguistic thinking, had started to appear towards the end of the twentieth century when discourse, which refers to context, came to be a main focus in the development of language teaching methodology. This is not to say that prior to this shift context was not a significant feature in Western linguistics. In fact, the British or London School of Linguistics was developed on the premise that language is meaningless when taken out of its context of situation, a premise which originated with Malinowski and developed into a theory by Firth. But British linguistics with its theory of the context of situation and prosody is not easy to apply both in the description of language as well as in the preparation of language teaching materials, compared to the American structural method. In the 1980s its practical application has been proven to be effective by the Birmingham group of TESL specialists led by John Sinclair in their approach of "language in use". And the teaching of English in Malaysia has greatly benefited from this trend.

As for the teaching of Malay, Za'ba's method which had ruled the classrooms from the 1920s was replaced by structural grammar in the 1970 s and this was later replaced in the 1980s by the sentencebased transformational- generative (TG) grammar with the publication of Tatabahasa Dewan. TG develops from Chomsky's theory of language and the mind, and has come to dominate the world's linguistic thinking since the early 1960s. Whether the philosophy of language behind TG is fully understood by the teachers in the language classroom is not the case in point, but a sure thing is that it is easier to produce teaching materials and to teach language based on de-contextualised sentences rather than otherwise.

Za'ba's approach to language teaching is not in terms of the grammaticality of the sentence, but in 


\section{CAPITAL KNOWLEDGE OF THE INDIGENOUS: AN APPRAISAL OF ZA'BA'S THOUGHTS ON LANGUAGE AND LINGUISTICS}

terms of thought structure. A sentence has a limitation in supporting such a structure which is seen clearer in the context of a longer discourse such as an exchange, a paragraph, and of course an essay.

Za'ba does not expound his ideas in clear statements of theory. He introduces topics according to his evaluation of their significance in languaging, and looks at each language from every possible angle in the way of giving an explanation. Every point he makes is accompanied by ample examples, and followed by his commentaries on the examples as though he is talking to a live audience. For a young inexperienced linguistic student, Za'ba's linguistics is not easy to follow. That describes the situation I found myself in about four decades ago when I tried to digest his ideas as found in his books. The reason was in the training I had in Western linguistics, a training which required me to look into clear statements of theories, and for the record, I had had the good fortune of being trained by the best in British linguistics. My difficulty in understanding Za'ba arose from my own folly in thinking that Za'ba's works were a treatise on the theory of language when in fact he offers none. Neither are these books (manuals per se) for the teaching of the Malay language in the classroom. The only thing he says about his works, especially Pelita Bahasa Melayu, is that he has been to a certain extent influenced by the grammars of English and Arabic, as he was proficient in both these languages. In actual fact, there is not much influence at all in his works from the grammars of English and Arabic. His knowledge of these two languages could have sharpened his sensitivity to the intricacies of the Malay language, and he seems to show more influence from Arabic and this is specifically in his formulation of the Jawi spelling.

When Za'ba wrote his books in the 1920s through the 1930s and into the 1940s, Raymond Firth had not yet formulated his theory of the context of situation for which the London school has become famous. Hence, Za'ba's inclusion in his books of the importance of context of situation cannot be interpreted as being a result of an influence from British linguistics. Za'ba went to teach Malay at the University of London School of Oriental and African Studies (SOAS) in $1951-1954$, after the PBM was published, and this was the last book on language he ever produced. And in his biography as told to Abdullah Hussain and Khalid Hussain, there is no mention of his meeting during his three-year sojourn in London, with the linguists of the Department of Phonetics and General Linguistics of SOAS, where Firth was head of department and Professor of General Linguistics. His academic activities were confined within the circle of the Department of Southeast Asia and the Islands.

Earlier on in this paper I have pointed out that Za'ba has given a guideline in four main points for good essay writing, and these four seem to correspond most accurately to Grice's four principles which have become the watchwords in discourse analysis. But Grice's principles were born long after Za'ba's, and Za'ba himself does not provide any evidence of having been influenced by any Western theory of discourse. His stance on synonymy is another case of his originality, which if he were to develop further would have given him a place in the development of the semantic field theory. His stance on the primacy of sound over spelling fits in well with the basic principle in modem linguistics. It is through pronouncing the words that one carries the authenticity of the language, and because of this his spelling system was formulated to reflect this authenticity.

His approach to language teaching is reflected in today's methods in language teaching especially in the teaching of English although these methods develop independently of Za'ba's. However, Za'ba's method has not made a comeback in the teaching of Malay as Malay grammarians are still bonded to transformational-generative grammar.

\section{Conclusion}




\section{CAPITAL KNOWLEDGE OF THE INDIGENOUS: AN APPRAISAL OF ZA'BA'S THOUGHTS \\ ON LANGUAGE AND LINGUISTICS}

Za'ba has definite and original ideas of what language, language learning and language teaching should be. The birth of these ideas precedes those of a similar nature which have become the mainstay in current theories in language learning and language teaching. Unfortunately these ideas are expounded in a narrative style of discourse, and their significance as theories or in the formulation of theories has become submerged in the throes of narration and illustration. Reading Za'ba, the student or reader has to go through the narration to identify those ideas, crystallise them and provide them with a theoretical underpinning.

The teaching of the nationallanguage of Malaysia for the purpose of making Malaysians proficient in the language so that there is an easy flow of communication between them, and between them and the government, has sidelined the function of language as a tool for thinking. Za'ba's grammar is written specifically with a focus on this particular function. As such, its usefulness is not evident to the method of teaching of the day, and that is language teaching for communication.

I have shown in this paper that with Za'ba there has already been in existence ideas of a theoretical value in the study of the Malay language which originate in the Malay world itself. All this while we know of these ideas, but have not come to identify their value within the mainstream theories in linguistics.

\section{References}

Abdullah Hussain and Khalid M. Hussain. (1974). Pendita Za 'ba Dalam Kenangan. (2 ${ }^{\text {nd }}$ Ed. 2000). Kuala Lumpur: Dewan Bahasa dan Pustaka.

Adnan bin Nawang. (1998). Za 'ba dan Melayu. Kuala Lumpur: Berita Publishing Sdn Bhd.

Asmah Haji Omar. (1992). The Linguistic Scenery in Malaysia. Chapter 10: The First Congress for Malay. Kuala Lumpur: Dewan Bahasa dan Pustaka.

Asmah Haji Omar. (2004). Muafakat Bahasa: Sejarah MBIM/MABBIM Sebagai Pembina Bahasa. Siri Monograf Sejarah Bahasa Melayu. Kuala Lumpur: Dewan Bahasa dan Pustaka.

Austin. J.L. (1960). How to Do Things with Words.: Oxford: Oxford University Press.

Grice, H.P. (1957). Meaning. Philosophical Review, 67. Re-printed in Steinberg and Jakobovits (Eds.), 1971, 53 - 59.

Hunt, Robert. (1996). William Shellabear: A Biography. Kuala Lumpur: University of Malaya Press.

Ungku A. Aziz. (1976). Footprints on the Sands of Tirnes --- The Malay Poverty Concept Over 50 Years Fron Za'ba to Aziz and the Second Malaysia Five Year Plan. In Bahasa, Kesusasteraan dan Kebudayaan Melayu: Esei-Esei Penghormatan Kepada Pendeta Za 'ba. Kuala Lumpur: Kementerian Kebudayaan, Belia dan Sukan Malaysia, 1976, 58- 92.

Zainal Abidin bin Ahmad. (1927). Kitab llmu Bahasa Melayu, Penggall dan II. Singapore: Malaya Publishing House Ltd. A Romanised edition is forthcoming, as ajoint effort of Dewan Bahasa dan Pustaka and Universiti Pendidikan Sultan Idris, Tanjong Malim, Perak. 
Zainal Abidin bin Ahmad. (1929). Rahsia Ejaan Jawi. Singapore: Malaya Publishing House Ltd. A Romanised edition is forthcoming,as ajoint effort of Dewan Bahasa dan Pustaka and Universiti Pendidikan Sultan Idris, Tanjong Malim, Perak

Zainal Abidin bin Ahmad. (2000). Pelita Bahasa Melayu, Penggal 1, II dan Ill. Edisi Baharu. Kuala Lumpur: Dewan Bahasa dan Pustaka. First published in 1940 (penggal I), 1946 (penggal II), and 1949 (penggal Ill) by the Malaya Publishing House Ltd., Singapore.

Zainal Abidin Ahmad, (2002). Ilmu Mengarang Melayu. Edisi Ejaan Rumi Baharu. Dengan pengenalan oleh Asmah Haji Omar. First published in 1934 by the Malaya Publishing House Ltd. Singapore. Kuala Lumpur: Dewan Bahasa dan Pustaka. 